\title{
Efficacy of Formulated Feed Preference and Stocking Density on Growth and Survival of Baby Pila globosa Reared in Laboratory Condition
}

\author{
Md. Shariful Islam ${ }^{1^{*}}$, A. F. M. Shofiquzzoha ${ }^{1}$ and Nilufa Begum ${ }^{1}$ \\ ${ }^{1}$ Bangladesh Fisheries Research Institute, Shrimp Research Station, Bagerhat, Bangladesh.
}

Authors' contributions

This work was carried out in collaboration among all authors. All authors read and approved the final manuscript.

Article Information

DOI: $10.9734 / A R R B / 2021 / v 36 i 730401$

Editor(s):

(1) Dr. Gonzalo Emiliano Aranda Abreu, Veracruzana University, Mexico.

Reviewers:

(1) Gebawo Tibesso Bedasso, Oromia Agricultural Research Institute, Ethiopia. (2) Amin Golpour Dehsari, Gorgan University of Agricultural Science and Natural Resource, Iran Complete Peer review History: https://www.sdiarticle4.com/review-history/70017

Original Research Article

Received 23 April 2021

Accepted 29 June 2021

Published 29 July 2021

\section{ABSTRACT}

Quality diet as food for raising freshwater snails under laboratory conditions has a significant effect on their growth and the number of egg clutches laid as well as on the size of the snail. Now a days, some innovative farmers of Bangladesh started snail culture within their fish farms in the view of producing snail to use as feed for their Prawn (Macrobrachiam rosenbergii), indigenous catfish (Clarius batrachus) farms, domestic duck farms and also as a protein supplement for preparing fish feed. From previous study we know that Bulinus nyassanus growth and survive rate was found well on locally formulated fish diet consisting of $30 \%$ crude protein with ingredients comprising fish meal, maize bran, rice bran, soya bean, wheat bran, hemicellulose (binder), vitamin premix and mineral premix. But no such research has been done in case of apple snail. The present study was aimed to investigate the feed formulation preferred by Pila globosa species and their effects on survival and growth of these snails in laboratory condition. Three type of formulated feed viz., pellet feed, fish meal and $50 \%$ fish meal $+50 \%$ crusted khudipana were used for the experiment in high and low stocking density of baby snails. The present findings shown that the diets in order of preference based on their effects on growth and survival of snails were formulated pellet feed, fish meal and $50 \%$ fish meal $+50 \%$ crushed khudipana. After rearing of 28 days, highest growth found $0.32 \mathrm{~g}$ with $86.66 \%$ survival with formulated diet in 60 nos/L stocking density and $0.35 \mathrm{~g}$ with $90 \%$ survival with 
formulated diet in 30nos/L stocking density. It's indicate that the snails reared on formulated pellet feed diets and lower stocking density gave better performance in terms of survival and mean growth rate than those reared on other diets.

Keywords: Freshwater apple snail; formulated feed; fish meal; management.

\section{INTRODUCTION}

Pila globosa (Swainson) is one of the most abundant molluscs which have huge commercially valued in Bangladesh. It is widely distributed and available in all types of temporary and permanent water bodies, such as ponds, canals, ditches, bee/s (a large surface static water body that accumulates surface runoff water through internal drainage channel), haors (a wetland ecosystem which physically is a bowl or saucer shaped shallow depression, also known as a back swamp), and baors (closed water body equivalent to an ox-bow lake, up to several hundred hectares) [1]. Muslim humans community of Bangladesh are not consumed Snails [2], however, identified 29 groups of tribal people that consume snail flesh. But, now a days different delicious snail meat food items is serving in different hotels of tourist city of Bangladesh like Cox-s-bazar, Khulna, Chittagong ets. Snail meat is instead more extensively used in freshwater prawn (Macrobrachium rosenbergii) farming in the south-western part of the country [3], which (prawn) is one of the major exports earning sectors in Bangladesh [4]. The average application of snail meat to prawn ponds is 66.5 $\mathrm{kg} \mathrm{ha}^{-1}$ day $^{-1}$ during June to October [5]. Snail meat is also utilized as supplementary feed in indigenous catfish (Clarius batrachus) farms and domestic ducks throughout most of the year [6]. Snail shell is used to produce lime and animal feed additive due to its rich $\mathrm{CaCO}_{3}$ content [7].

When experimental freshwater snails cultured in the laboratory conditions are fed with vegetations and artificial feeds. Quality diet provided as food for raising freshwater snails under laboratory conditions, has a significant effect on their growth and the number of egg clutches laid as well as on the size of the snail. Also, the raising of snails on a mixture of foods resulted in better results in terms of snail survival and prevalence of infection [8].

Now a days, some innovative farmers of Bangladesh started snail culture within their fish farms in the view of producing snail as feed for their Prawn (Macrobrachiam rosenbergii), indigenous catfish (Clarius batrachus) farms, domestic duck farms and also as a protein supplement for preparing fish feed. The underlying reasons to culture snail are to reduce feed cost for fish production and pressure of natural snail population. However, there are many scientific questions on how the snail farming is going on and ways of using snail as a feed aquaculture production.

Different researchers from around the world give their attention on snail culture and found remarkable results. Such as Aziz and Raut [9] done comprehensive research on Lymnea snail cultured in the laboratory to determine the thermal effect on the life cycle parameters and reported that that snails sustained on different vegetables which comprised of lettuce (Lactuca sativa), mustard (Brassica nigra), radish (Raphanus sativus). Spinach (Spinancea oleracea) and aquatic weed (Chara vallisneria). Rondeland et al. [10] also observed higher cercarial production in snails raised with lettuce Tetraphyll combinations than those raised with only lettuce. Lundeba et al. [11] also reported that Bulinus nyassanus feed and survive well on locally formulated fish diet consisting of $30 \%$ crude protein with ingredients comprising of fish meal, maize bran, rice bran, soya bean, wheat bran, hemicellulose (binder), vitamin premix and mineral premix. But no such research has been done in case of apple snail.

However, not much literature has shown trials with formulated diets. Formulated feeds are expected to be cheaper and more readily available all year round. If a farmer knows the specific feed preferences of this snails then he/she get interest on snails farming. The present study was designed to investigate the feed formulation preferred by Pila globosa species and their effects on the survival and growth of these snails in the laboratory. It is hoped that this research work will contribute immensely to the search for potential formulated feeds for laboratory rearing of experimental freshwater snails. 


\section{MATERIALS AND METHODS}

\subsection{Study Area and Study Period}

The study was conducted in the Wet Laboratory of Bangladesh Fisheries Research Institute (BFRI), Shrimp Research Station (SRS), Bagerhat $\quad\left(22^{\circ} 641959^{\prime} \mathrm{N} \quad 8^{\circ} 805692 ' \mathrm{E}\right)$, Bangladesh. Rearing of Pila globosa was conducted for a period of 04 weeks (April-May) with three trials (each trail of 28 days of culture) in 2020 in nine aquariums.

\subsection{Methodology}

Study on the efficacy of formulated feed preference and stocking density on the growth and survival of apple snail, Pila globosa in aquarium was carried out in nine aquarium of $4 \mathrm{~L}$ volume each. Management techniques are as follows.

\subsubsection{Pre-stocking management}

Aquariums were filled with ground water up to $1 \mathrm{~L}$ directly from SRS pond using pumps. All time aeration facility was established for all aquariums. Stocking was done as per following experimental design.

All baby snails (Avg. weight 0.02g) were collected from large aquarium of SRS wet laboratory where they spent 20-25 days after laid out egg from mother snail.

\subsubsection{Post-stocking management}

\subsubsection{Feeding and monitoring}

All types of experimental food were provided at the rate of $10 \%$ body weight of baby snail for all treatments. Growth and well-being of the baby snails was checked at weekly interval. After 28 days of nursing, all snails of both experiments were harvested first by scoop net from the aquarium. Growth (Weight basis) and survival of snails were estimated.

\subsubsection{Aquarium monitoring and water quality management}

During experimental period water in the aquarium was changed every seven days interval and continuous aeration was provided full time throughout the experiment period. In addition, the water quality of the aquarium is kept suitable for cultivation.

\subsection{Statistical Analysis}

T-test, ANOVA and correlation of growth performance and production of snail under experiments were calculated using SPSS package programme.

\section{RESULTS AND DISCUSSION}

After 28 days of culture weight of snails found $0.32 \pm 0.04 \mathrm{~g}, 0.29 \pm 0.03 \mathrm{~g}$ and $0.26 \pm 0.01 \mathrm{~g}$ in T1, T2 \& T3 respectively (Table 3 \& Fig. 1) and the differences in final weight among three treatments under high stocking density experiment were not significant $(p<0.05)$. On the other hand weight of snails found $0.35 \pm 0.01 \mathrm{~g}$, $0.33 \pm 0.03 \mathrm{~g}$ and $0.28 \pm 0.02 \mathrm{~g}$ in $\mathrm{T} 4, \mathrm{~T} 5$ \& $\mathrm{T} 6$ respectively (Table 4 \& Fig. 1) and the differences in final weight among three treatments under low stocking density were found significant $(p<0.05)$. As shown in Table 4 \& 5 , mean weight of snails recorded the highest in aquarium using pellet feed followed by aquarium with fish meal and aquarium with $50 \%$ fish meal $+50 \%$ crusted khudipana. Formulated pellet feed is exhibited the best results for baby snails rearing in laboratory condition.

Average survival of stocked baby snails was found the highest of $90 \%$ in aquarium with low stocking density and using formulated pellet feed (T6) followed by $86.6 \%$ survival in aquarium with low stocking density \& using pellet feed (T1), $85 \%$ in aquarium with high stocking density and using fish meal (T2), $70 \%$ in aquarium with low stocking density and using fish meal (T5), 50\% in aquarium with low stocking density and using $50 \%$ fish meal $+50 \%$ khudipana (T3) and $30 \%$ in aquarium with high stocking density \& using fish meal (T3). The differences in survival among six treatments were significant $(p<0.05)$. This study showed that low stocking density exhibited better results of baby snails rearing than high stocking density.

Water quality parameters of all aquariums were congenial for baby snail's growth and development (Table 6).

The present research has shown the food preferences of apple snail ( $P$. globosa) species under laboratory conditions. The diets in order of preference based on their effects on the growth and survival are formulated pellet feed, fish meal and $50 \%$ fish meal+ $50 \%$ crushed khudipana. 
Table 1. Experimental design of high stocking density of baby apple snail

\begin{tabular}{llll}
\hline Treatments & Name of Feed & Stoking Density & Replications \\
\hline $\mathrm{T}_{1}$ & Formulated Pellet Feed (30-35\% Protein) & $60 \mathrm{nos} / \mathrm{L}$ & 3 \\
$\mathrm{~T}_{2}$ & Fish Meal (95-99\% Protein) & & \\
$\mathrm{T}_{3}$ & $50 \%$ Fish Meal $+50 \%$ Crushed Khudipana & & \\
\hline
\end{tabular}

Table 2. Experimental design with low stocking density of baby apple snail

\begin{tabular}{llll}
\hline Treatments & Name of Feed & Stoking Density & Replications \\
\hline $\mathrm{T}_{4}$ & Formulated Pellet Feed (30-35\% Protein) & 30 nos $/ \mathrm{L}$ & 3 \\
$\mathrm{~T}_{5}$ & Fish Meal (95-99\% Protein) & \\
$\mathrm{T}_{6}$ & $50 \%$ Fish Meal + 50\% Crushed Khudipana & & \\
\hline
\end{tabular}

Table 3. Proximate composition of formulated pellet feed

\begin{tabular}{ll}
\hline Parameters & Formulated Feed \\
\hline Crude Protein & 34.80 \\
Crude Fat & 8.40 \\
Ash & 12.30 \\
Fibre & 5.63 \\
NFE & 30.03 \\
GE $\left(\mathrm{kJ} \mathrm{g}^{-1}\right)$ & 16.50 \\
\hline
\end{tabular}

Table 4. Growth \& Survival rate of snails under high stocking density (60Nos/L) experiment

\begin{tabular}{llll}
\hline Treatments & Initial Weight (g) & Final Weight (g) & Survival Rate (\%) \\
\hline T1 & 0.02 & $0.32^{\mathrm{a}}$ & $86.66^{\mathrm{a}}$ \\
T2 & 0.02 & $0.29^{\mathrm{a}}$ & $85^{\mathrm{a}}$ \\
T3 & 0.02 & $0.26^{\mathrm{a}}$ & $30^{\mathrm{b}}$ \\
\hline
\end{tabular}

${ }^{*}$ Figures in the same column with different superscripts are significantly different $(P>0.05)$.

Table 5. Growth \& Survival rate of snails under low stocking density (30Nos/L) experiment

\begin{tabular}{llll}
\hline Treatments & Initial Weight $\mathbf{( g )}$ & Final Weight $\mathbf{( g )}$ & Survival Rate (\%) \\
\hline T4 & 0.02 & $0.35^{\mathrm{a}}$ & $90^{\mathrm{a}}$ \\
T5 & 0.02 & $0.33^{\mathrm{a}}$ & $70^{\mathrm{b}}$ \\
T6 & 0.02 & $0.28^{\mathrm{b}}$ & $50^{\mathrm{c}}$ \\
\hline
\end{tabular}

${ }^{*}$ Figures in the same column with different superscripts are significantly different $(P>0.05)$.

Table 6. Water quality parameters of aquariums

\begin{tabular}{llll}
\hline Parameters & Average Value \pm SD & Parameters & Average Value \pm SD \\
\hline Air Temperature & $30 \pm 2.13^{\circ} \mathrm{C}$ & $\mathrm{CO}_{2}$ & $1.2 \pm 0.21 \mathrm{mg} / \mathrm{l}$ \\
Water Temperature & $29 \pm 2.84^{\circ} \mathrm{C}$ & Ammonia & $0.020 \pm 0.002 \mathrm{mg} / \mathrm{l}$ \\
Moisture & $82 \pm 3.29 \%$ & Nitrite & $0.13 \pm 0.03 \mathrm{mg} / \mathrm{l}$ \\
$\mathrm{pH}$ & $8.02 \pm 0.31 \mathrm{mg} / \mathrm{l}$ & Hydrogen sulfide & $0.02 \pm 0.004 \mathrm{mg} / \mathrm{l}$ \\
DO & $4.38 \pm 1.54 \mathrm{mg} / \mathrm{l}$ & & \\
\hline
\end{tabular}

The snails reared using formulated pellet feed diets gave better performance in terms of survival and mean growth rate than those reared on other diets. This agrees with the findings of Lundeba et al. [11] reported that Bulinus nyassanus feed and survive well on locally formulated fish diet consisting of $30 \%$ crude protein with ingredients comprising of fish meal, maize bran, rice bran, soya bean, wheat bran, hemicellulose (binder), vitamin premix and mineral premix. The present study also agrees with the findings of Ismail and Haroun (2001), which observed that a mixture of foods resulted in better fitness in terms of survival and prevalence of infection. In case of formulated pellet feed there are so many ingredient mixed 
like fish meal, rice bran, rice polish, mustard oil cake etc. In the findings of Ogbu, et al. [12], the feed preferences of snails also showed preciously which is also totally matched with the present findings. The results of the study [13] showed that diet has pronounced effect on body weight gain, shell circum ference gain, shell length gain, shell percentage, feed intake and feed conversion ratio; diet containing poultry droppings was cheapest and excellent for snail production which agrees with the present finds. The study has also shown the experimental procedure that ensures the growth, survival and adaptability of Pila globosa snail species in the laboratory.

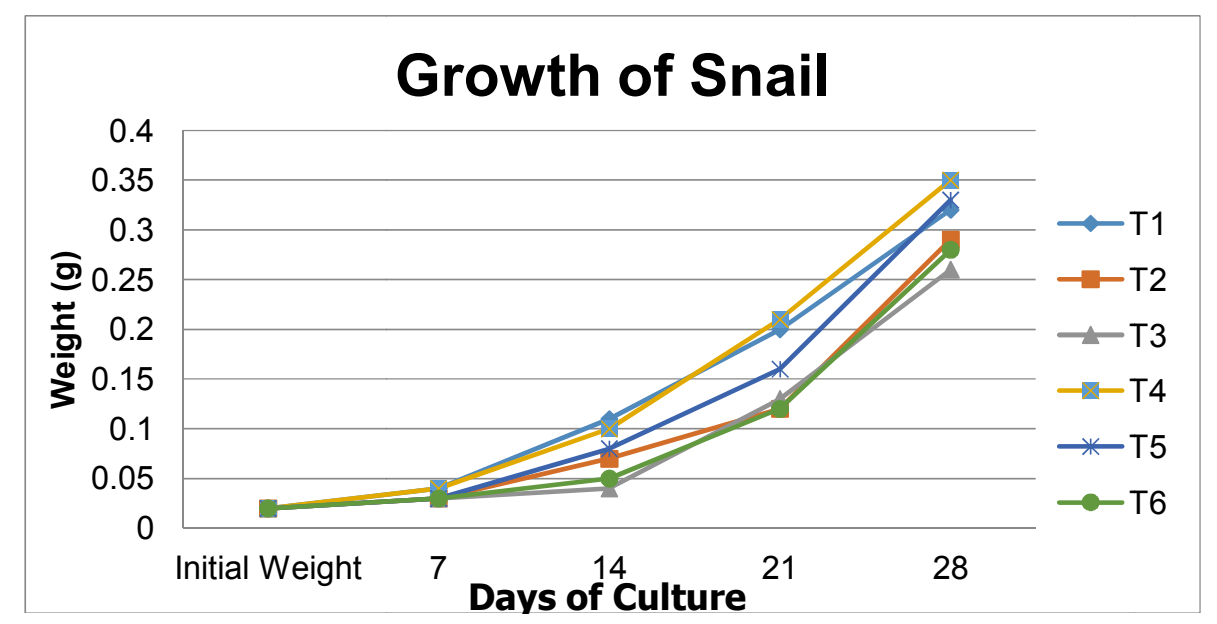

Fig. 1. Growth rate of baby snails
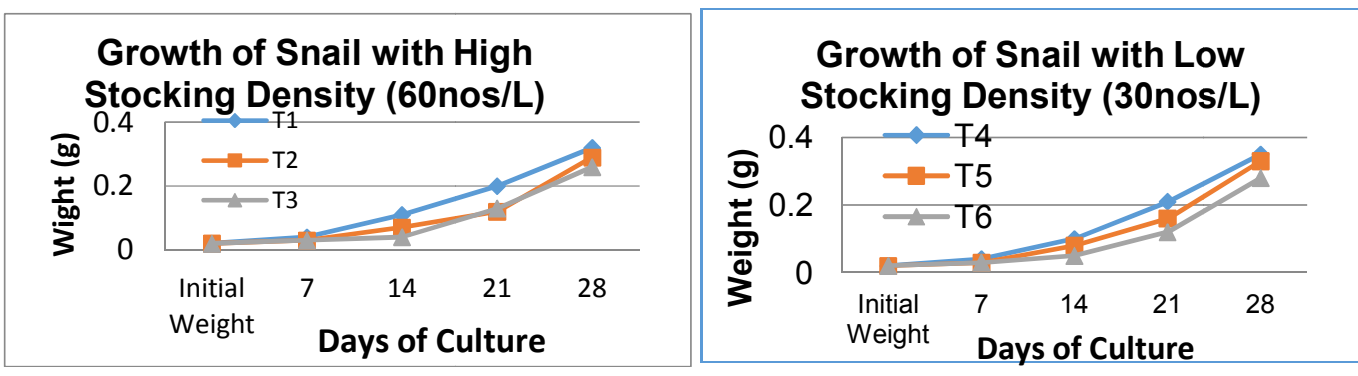

Fig. 2. Growth rate of baby snails in a) High Stocking density; b) Low stocking density

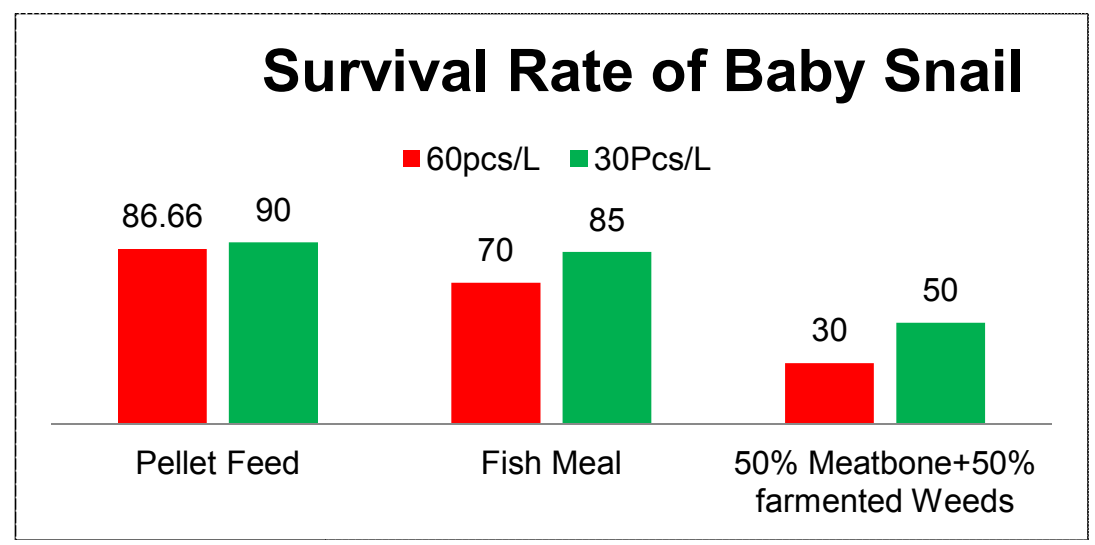

Fig. 3. Survival rate of baby snails in different stocking densities 


\section{CONCLUSIONS}

This was a preliminary research and more research work should be accomplished for development of culture and rearing techniques. Experimental research achievement is must needed to develop snail culture package to promote at the farmer level for broader benefits that will be helpful for future arena of this inductry.

\section{COMPETING INTERESTS}

Authors have declared that no competing interests exist.

\section{REFERENCES}

1. Nath RD, Rahi ML, Hossain GS, Huq KA. Bangladesh status of fresh water snail in Khulna district. Bangladesh Res. Pub. J. 2008;1(4):337-347.

2. Saha BK. Ecology and bio-eonomics of the freshwater edible snails of Bangladesh. PhD dissertation. Rajshahi University, Bangladesh. 1998;162 .

3. Baby RL, Hasan I, Kabir KA, Naser MN. Nutrient analysis of some commercially important molluscs of Bangladesh. J. Sci. Res. 2010;2(2):390-396.

4. DoF. National fish week compilation. Department of fisheries (DoF), Ministry of Fisheries \& Livestock. Dhaka, Bangladesh. 2011;136.

5. Ahmed N, Demaine $\mathrm{H}$, Muir JF. Freshwater prawn farming in Bangladesh: History, present status and future prospects. Aqua. Res. 2008;39:806819.

6. Banglapedia. National encyclopedia of Bangladesh. Retrieved September 23, 2011; 2006.
Available:http://www.banglapedia.org/httpd ocs/HT/S_0437.HTM

7. Nath RD, Rahi ML, Hossain GS, Huq KA. Bangladesh status of fresh water snail in Khulna district. Bangladesh Res. Pub. J. 2008;1(4) 337-347.

8. Ismail NM, Haroun NH. Effect of various foods on Biomphalaria alexandrina and Bulinus truncatus and their susceptibility to schistosome miracidia. Journal of Egyptian Society of Parasitology. 2001;31:939-952.

9. Aziz MA, Raut SK. Thermal effect of the life cycle parameters of the medically important freshwater snail species Lymnaea (Radix luteola (Lamark). Memorias Do Instituo Oswaldo Cruz. 1996; 91(1):129-130.

10. Rondeland D, Deneve C, Belfaiza $M$, Mekroud A, Abrous M, Monocef $M$. Variability in the prevalence of infection and cercarial production in Galba truncatula raised on a high quality diet. Bulletin of the Society of Zoology of France. 2004;118:185-193.

11. Lundeba M, Likongwe JS, Madsen $\mathrm{H}$, Stauffer JR. Preliminary study on the culture and breeding of Bulinus nyassanus (Mollusca: Pulmonata) under laboratory conditions. African Zoology. 2006;41(1): 143-144.

12. Ogbu CC, Ani AO, Emeh M. Feed preferences and feeding behaviour of two species of african giant land snails. Archivos de Zootecnia. 2014;63(242):337347.

13. Eze JN, Akpodiete OJ, Okonkwo JC, Eruvbetine D. Cost benefit analysis and effects of feed preference on performance of giant african land snail (Archachatina marginata) reared intensively. Journal of Applied Agricultural Research. 2013;5(1): 83-90.

(c) 2021 Islam et al.; This is an Open Access article distributed under the terms of the Creative Commons Attribution License (http://creativecommons.org/licenses/by/4.0), which permits unrestricted use, distribution, and reproduction in any medium, provided the original work is properly cited.

Peer-review history:

The peer review history for this paper can be accessed here: https://www.sdiarticle4.com/review-history/70017 